\title{
Seasonal variation in the litter size in relation with variations in the ovulation rate and the embryo mortality in the sow
}

\author{
Françoise MARTINAT-BOTTE *, P. DANDO **, J. GAUTIER *** \\ et M. TERQUI *** \\ * I.T.P., 149, rue de Bercy, F 75595 Paris Cedex 12 \\ **I.N.R.A., Station de Génétique animale, Domaine de Galle, F 18800 Avord \\ **** I.N.R.A., Station de Physiologie de la Reproduction, F 37380 Monnaie
}

A variation in the litter size, ovulation rate and embryo mortality was noticed when analysing two sources of data.

The mean number of piglets born was maximum for litters conceived in August, September, November and minimum for those conceived in December and January. On an average a difference of one piglet was noticed between the two extreme months, i.e., November, January. Piglets were all issued from dams in fourth gestation $(\mathrm{N}=10981)$, where prolificacy reaches a plateau and varies little.

Variation in the ovulation rate during the year in sows slaughtered at 30 days post coitum in third and fourth gestation $(N=415)$ was parallel to that of the number of embryos and that of the litter size. The maximum corresponded to fertilization in August, September, October, November and the minimum to fertilization in December, January and February. On an average, a difference of two ovulations was noticed between FebruaryOctober.

The embryo mortality varied according to the ovulation rate; beyond 15 ovulations it was equal to 4 embryos or more. The analysis according to the month of mating showed that the embryo losses were maximum in March and minimum in November for the two groups studied (14-15 and 16-17 ovulations).

\section{Economic and technical consequences of sow culling}

\author{
J. DAGORN *, Françoise DUFOUR * et J. HAUTCOLAS ** \\ * I.T.P., Service Conduite d'Elevage, \\ 149, rue de Bercy, F 75595 Paris Cedex 12 \\ *:*I.N.R.A., Laboratoire d'Economie rurale de Grignon, \\ F 78850 Thiverval-Grignon
}

Have sows to be culled after the first, the second or the third return to heat? 'To solve this problem a simulatory assay was made on a herd of 70 sows kept in batches of seven each for 4 fertilization levels.

The mean number of sows to be mated was $19,16,14$ and 12 sows for a fertilization level of $60,70,80$ and 90 p. 100 , respectively.

When the number of tolerated returns to heat increased from 0 to 2 , the number of gilts to introduce into the batches decreased by 50 to 75 p. 100 .

For a given fertilization level, the maximum of pigs produced with a minimum amount of feed (the best profit margin) was always obtained with two tolerated returns to heat. 
For all criteria studied the differences were all the larger as the fertilization level of the herd was low and in particular when changing from 0 to 1 return.

In the case where sows can easily be reintegrated into the batches ( 1 or 3 week-intervals between batches) mating of sows returning 1-2 times to heats is more advantageous for the breeder.

\title{
The objectives of pig breeding in France
}

\author{
L. OLLIVIER \\ I.N.R.A., Station de Génétique quantitative et appliquée, \\ Centre de Recherches zootechniques, \\ F 78350 Jouy-ent-Josas
}

Several possibilities exist for defining the overall objective of pig production, for choosing the elementary objectives and for combining them. The goals which have been defined ten years ago are re-examined on account of changes in the economic conditions of pig production in France, and particularly the use of the European system of carcass grading since 1972. Prediction equations for carcass value (using measurements obtained in the standardized Parisian jointing system) have been derived from a sample of 15648 female pigs jointed and graded in the progeny-lesting station from 1972 to 1978 . These equations are similar to the prediction equations for muscle percentage obtained by Hamelin (see Naveau and PommereT, 1979, Techni-Porc, 2 (4), 7-12). Furthermore, though the present grading system practically ignores meat quality, is inclusion among the selection objectives is considered. A modification of the grading sysiem in order to take meat quality into account appears to be desirable.

\section{Genetic parameters of Large White and French Landrace progeny testing female pigs over the 1970-1978 period}

\author{
L. OLLIVIER, A. DERRIEN et M. MOLENAT \\ I.N.R.A., Station de Génétique quantitative et appliquée, \\ Centre de Recherches zootechniques, \\ F 78350 Jouy-en-Josas
}

On a sample of 4822 Large White and 2777 French Landrace pigs tested from 1970 to 1978 in six progeny-tesiing siations, the following variables were considered : growth traits over the $35-100 \mathrm{~kg}$ liveweight interval, i.e. individual average daily gain (ADG) and food conversion ratio (FCR) on a two-sib-pen basis, carcass (using the standardized Parisian jointing system) and meat quality traits after slaughter at $100 \mathrm{~kg}$ liveweight. Heritability estimates for ADG and FRC were close to those obtained over the same period on individuallyfed boars of the same breeds in the performance-testing stations (Ollivier et al., 1980, Techni-Porc, $3(1), 7-12)$. The highest heritabilities were obtained for the weights of loin $(0.60 \pm 0.06)$ and backfat $(0.61 \pm 0.06)$. Among the three meat quality traits considered ( $\mathrm{pH}$, colour, water-holding capacity), the most highly heritable was colour, measured by a reflectometer $(0.27 \pm 0.05)$. The dam components of varianca largely exceeded the sire components, especially for $\overline{A D G}$ (sib correlation 0.78 ) and meat quality (sib correlation 0.30 ). This may be 